\title{
The mediating effect of consumers' price level perception and emotions towards supermarkets
}

\author{
A. Celil Cakici
Mersin University, Mersin, Turkey, and \\ A. Celil Cakici
Mersin University, Mersin, Turkey, and \\ Sena Tekeli \\ Toros University, Mersin, Turkey
}

\begin{abstract}
Purpose - This study aims to reveal the impact of consumers' price sensitivity on their purchase intention within the scope of supermarkets. Besides, the study aims to examine the impact of consumers' price sensitivity on their price perception level and emotions and the impact of consumers' price level perception and emotions toward supermarkets on their purchase intention. It also aims to detect the mediating effects of consumers' price level perception and emotions toward supermarkets between their price sensitivity and purchase intention.

Design/methodology/approach - The quota sampling method was used to form the study sample. The population was 20-69-year-old consumers. The study sample included 513 consumers, 276 of whom were men, and 237 of whom were women. Data were collected via a questionnaire by the researchers in Mersin's (Turkey) five central counties. Explanatory and confirmatory factor analyses and structural equation models were used to analyze data.

Findings - Consumers' price sensitivity, perception of cheapness, perception of expensiveness and positive emotions toward supermarkets affect their purchase intention. Besides, price sensitivity affects their perception of cheapness while it does not affect their perception of expensiveness. It influences negative emotions, but not on positive emotions. Consumers' perception of cheapness and perception of expensiveness have impacts on positive emotions toward supermarkets. It was additionally discovered that perception of cheapness and perception of expensiveness affected negative emotions toward supermarkets. A contributed finding was that perception of cheapness had a partial mediating role between price sensitivity and purchase intention.

Practical implications - The study provides managerial implications in terms of understanding consumers' behavioral changes, developing effective pricing strategies and achieving competitive advantages over the other retailing companies.

Originality/value - The study illustrates that consumer behavior can be explained by a theoretical construct considering the price perception levels and emotions toward supermarkets in examining the effect of consumers' price sensitivity on their purchase intention. Therefore, it contributes to explain consumers' behavior by bringing the stimulus-organism-response (SOR) model into a theoretical construct.
\end{abstract}

Keywords Price sensitivity, Price level perception, Emotion toward supermarkets, Purchase intention Paper type Research paper

\section{Introduction}

Brand perception and attention, attitudes toward brands, purchasing intention and actual purchasing behavior are the possible consumer reactions. These occur as a result of the consumer purchasing decision process (Pirachi, 2019). To understand how consumers make their purchasing decisions, it is necessary to identify the factors under these behaviors

(C) A. Celil Cakici and Sena Tekeli. Published in European Journal of Management and Business Economics. Published by Emerald Publishing Limited. This article is published under the Creative Commons Attribution (CC BY 4.0) licence. Anyone may reproduce, distribute, translate and create derivative works of this article (for both commercial and non-commercial purposes), subject to full attribution to the original publication and authors. The full terms of this licence may be seen at http:// creativecommons.org/licences/by/4.0/legalcode

This research did not receive any specific grant from funding agencies in the public, commercial, or not-for-profit sectors.

Received 5 December 2020 Revised 7 February 2021 12 April 2021 22 May 2021 Accepted 9 June 2021 
EJMBE 31,1

(Kotler and Keller, 2012). Different studies (Rana et al., 2015; Mondal et al., 2017; Hanahsya, 2018) reveal the factors influencing consumers' purchasing behaviors in retailing.

Various models are trying to explain from different perspectives how and why consumers behave as they do. One of the widely used theoretical models to explain consumers' behavior is Mehrabian and Russell's (1974) stimulus-organism-response (SOR) model (Zhu et al., 2015; Hetharie et al., 2019). According to the SOR model, an environmental stimulus (S) affects someone's internal evaluation (O), which leads to a response (R) (Mehrabian and Russell, 1974 cited in Hetharie et al., 2019). In other words, marketing mix variables and other environmental inputs, such as visual appeal, information, atmosphere, social cues, accessibility and customer services (Vergura et al., 2020), influence consumers' emotions (Mowen and Minor, 2002; Zhu et al., 2015), environmental interpretations, conscious and unconscious perceptions (Donovan and Rossiter, 1982) and attitudes (Zhu et al., 2015), which result in purchase intention or actual purchase behavior (Zhu et al., 2015).

Since it has broad applicability, many researchers have adopted the SOR model in their study context and integrated cognitive and affective factors into the framework (Kim et al., 2018). There have been research (Donovan and Rossiter, 1982; Chang et al., 2011; Viera, 2013; Goi et al., 2014; Zhu et al., 2015; Hetharie et al., 2019) in retailing modified the SOR model. Even though research-modified SOR models exist, the results are not consistent, and general models have not been proposed (Goi et al., 2014). Besides, Graciola et al. (2018) suggested examining price sensitivity within the scope of both lower and higher-level stores including the impact of negative emotions on price image. Thus, guided by the SOR model and consumers' purchasing behavior literature in this study includes price sensitivity toward supermarkets as the independent variable (the stimulus), consumers' price level perception and emotions toward supermarkets as the mediator (the organism) and purchase intention as the dependent variable (response).

Price sensitivity, which is one of the influential factors in consumers' purchasing decisions (Chua et al., 2015; Uslu and Huseynli, 2018), explains how consumers react to changes in price levels (Mamun et al., 2014). If managers have more information about consumers' reviews and their reaction to prices, they find effective ways to appeal to certain consumers and become more successful in increasing profitability rates (Ramirez and Goldsmith, 2009). While price level reflects the amount of money paid to buy the same good or service (Zielke, 2006), the price level perception reflects how cheap or expensive the store is according to consumers' point of view (Zielke, 2010). The results of the consumers' price level perception include consumer beliefs (price evaluations and price justice) and consumer behavior (store selection, selection delay and purchase amount) (Hamilton and Chernev, 2013). Apart from the price level perception, both positive and negative emotions can affect the purchase intention significantly (Kim et al., 2016; Graciola et al., 2018). Purchase intention can be defined as the desire to buy a product from a particular store (Rana et al., 2015).

The present study intends to confirm the causal relationships between the stated variables within the scope of supermarkets, depending on Mehrabian and Russell's (1974) SOR model. The main objective is to examine the influence of consumers' price sensitivity on their purchase intention. The second objective is to detect whether consumers' price sensitivity affects consumers' price level perception - both perception of cheapness and perception of expensiveness - and positive and negative emotions toward supermarkets. The third objective is to scrutinize the influence of consumers' price level perception and emotions toward supermarkets on their purchase intention. The fourth objective is to examine whether consumers' price level perception influences their positive and negative emotions toward supermarkets. The last objective is to detect the mediating role of consumers' price level perception - both perception of cheapness and perception of expensiveness - and positive and negative emotions toward supermarkets between their price sensitivity and purchase intention. 
As a result, it is expected to contribute both theoretically and practically to the understanding of the consumers' behaviors within the scope of supermarkets. At the theoretical level, contributions are provided in terms of the modification of the SOR model, the confirmation of the previous studies and the mediating impacts of consumers' price perception and emotions. At the practical level, contributions are stated in terms of understanding consumers' behavioral changes, developing effective pricing strategies and achieving competitive advantages over the other retailing companies.

\section{Theoretical framework and research hypotheses}

Purchasing behavior is a process that involves a particular set of efforts to solve a problem. The consumer decision-making process involves five steps: determining a problem, searching information, evaluating alternatives, purchase decisions and postpurchase evaluation. Knowing and understanding every step involved in consumers' decisionmaking process helps marketing professionals to communicate with consumers. In addition, this enables marketers to reach successful results in guiding consumers to purchase products or services (Clow and Baack, 2016). Purchase intention is one of the possible consumer reactions that occurred as a result of the consumer decision-making process (Pirachi, 2019). Purchase intention is "the willingness of a customer to buy a product or service in a certain condition" (Usman and Okafor, 2019).

Different studies have adapted the SOR model to explain the factors affecting consumers' purchase intention. According to the SOR model, developed by Mehrabian and Russell (1974), an emotional, cognitive and process element exists in humans to receive a stimulus and then respond it. Thus, the process starts with receiving a stimulus then continues in a response through eliciting the organism itself (Meylina and Chandra, 2018). In the original model, stimulus refers to the element affecting an individual's internal state. The organism is defined as the internal process and the outcome of the stimulus. It usually has a mediating role between the stimulus and the response. The response is the final outcome such as purchase intention or actual purchase behavior (Emir et al., 2016). The model has been used in advertising, computer and website experience, and many other consumer behavior domains (Islam and Rahman, 2017).

Chang et al. (2011) adapted the SOR model in their study conducted in the retailing domain. They included the social, ambient and design characteristics of the retail environment, consumers' positive emotional responses to the retail environment, impulse buying behavior and the moderating effect of hedonic motivation into the model as variables. Viera (2013) conducted a meta-analysis to summarize the findings of the studies based on the SOR model. Both arousal and pleasure create a variation on utilitarian and hedonic motivation while shopping. Comparing to other variables searched in the studies, arousal-hedonic and pleasurehedonic relationships form strong influences. Hetharie et al. (2019) modified the SOR model by including the stimuli from the store environment, social factors and consumers' fashion involvement in impulsive buying; consumers' emotional gratification as the organism and impulsive buying and postpurchase regret as the response. Based on the SOR framework, Laato et al. (2020) proposed a structural model by including exposure to online information as the stimulus and unusual purchases and voluntary self-isolation as the responses.

As it was stated in the introduction, this study includes price sensitivity as the independent variable (the stimulus), consumers' price level perception and emotions toward supermarkets as the mediator (the organism) and purchase intention as the dependent variable (response). It examines the direct and indirect relations between these variables in the retailing domain within the scope of supermarkets, which is one kind of the retail stores (Kotler and Armstrong, 2012) and use a combination of price, goods and services to influence consumers' purchasing decisions (Leal, 2014).

Consumers' price level 
EJMBE 31,1

Price sensitivity is a fundamental element to evaluate the target customers since it has a strong effect on companies' bottom line. Businesses need to understand the price sensitivity in determining pricing strategies (Uslu and Huseynli, 2018). Price sensitivity is the extent to which consumers differ in their response to price differences and changes in a product (Kagan, 2020). Price sensitivity may vary according to the different conditions. The situational factors such as income consumption conditions and social content have an impact on price sensitivity. The difference in price sensitivities in functional consumption and hedonic consumption increases as income increases (Wakefield and Inman, 2003). Price sensitivity can stand out among the brands in the same product category, among the product categories in the same store and among the product categories in different stores (Hoch et al., 1995). Even when the packages of competitive products are the same size, when unit price is mentioned, consumers are more motivated to choose cheaper goods. This effect causes changes in consumers' preferences in favor of low-priced products. In addition, unit pricing increases consumers' price sensitivity in the context of price reduction (Yao and Oppewal, 2016). According to Ghali-Zinoubi and Toukabri (2019), consumers' price sensitivity and involvement are effective in consumers' intent to buy an organic product, if the product is regional, and consumers' involvement is high, but price sensitivity is low. Similarly, Walia et al. (2020) found price sensitivity is one of the significant factors affecting the consumers' purchase intention within the scope of retail outlets selling green products. Accordingly, the following hypothesis can be established as follows:

\section{H1. Consumers' price sensitivity affects their purchase intention.}

Price sensitivity involves awareness of price distribution, requiring considerable time and psychological effort. The number of alternative retail outlets has been increasing. Thus, households with more substitution possibilities may have more price sensitivity unless the prices in different stores are equivalent (Hoch et al., 1995). In general, while consumers with high price sensitivity respond strongly to a price change, consumers with low price sensitivity have a relatively weak response to the price change (Han et al., 2001; Kagan, 2020). The fundamental issue is whether the customers notice the changes in price and respond to these changes as expected. Thus, customers' way of price level perception is as important as the price itself. What consumers perceive does not always match with what retailers provide. A traditional grocer determines such a price to align price perception with high-end value (Heda et al., 2017). The price level perception reflects how cheap or expensive the store is according to consumers' point of view (Zielke, 2010). Consumers with low price sensitivity can positively evaluate the expensive perception of supermarkets and start thinking they are not expensive (Backman and Crompton, 1991). Therefore, it can be concluded that consumers' price sensitivity may affect their price level perception and emotions. The hypotheses based on this conceptual information are as follows:

H2. Consumers' price sensitivity affects their perception of cheapness.

H3. Consumers' price sensitivity affects their perception of expensiveness.

H4. Consumers' price sensitivity affects their positive emotions toward supermarkets.

H5. Consumers' price sensitivity affects their negative emotions toward supermarkets.

Price level perception can differ according to consumers. Some consumers can evaluate a market's price level by comparing it with the other markets' price levels. Thus, they reach a judgment regarding the low or high price level of that market. Some consumers assess the sacrifices made with the benefits obtained. This results in a perception of whether the market is reasonable in terms of price-performance ratio (Zielke, 2011). While the price perceived as very high by the consumers causes them to hesitate while purchasing a product, the price 
perceived as reasonable or suitable for the product enables consumers to be willing to buy a product (Boonpattarakan, 2012). In their study conducted within a grocery-shopping context, Fecher et al. (2019) found price presentation (unit price and retail price) affects price perception depending on the size and the package of the product; thus, consumers' price level perception influences their purchase intention. The hypotheses created based on this conceptual information are as follows:

H6. Consumers' perception of cheapness affects their purchase intention.

H7. Consumers' perception of expensiveness affects their purchase intention.

Apart from the price level perception or the value obtained in return for the money paid, emotions can affect the purchase intention significantly (Kim et al., 2016; Graciola et al., 2018). Emotional responses play a significant role in forming consumers' impressions. While evaluating products, consumers depend on their emotions (Ladhari et al., 2017). Emotion is intimately connected with cognition, and how these psychological processes interact with each other to affect behavior has been an active field of research (Shukla et al., 2019). Emotions are formed with high intensity, rapid change and short-lasting (Spinelli and Monteleone, 2018). In short, emotion is "a complex reaction pattern, involving experiential, behavioral and physiological elements, through which an individual attempts to deal with a personally significant matter or event" (American Psychological Association [APA], 2020). Positive emotions can be defined as pleasant responses toward the world, which are complex and targeted. On the other hand, negative emotions can be considered unpleasant or unhappy responses to the environment. A negative emotion discourages people. While satisfaction, interest, joy, amusement, happiness, love, serenity, awe and contentment are some common positive emotions, sadness, rage, anger, loneliness, disgust, melancholy and annoyance are most commonly felt negative emotions (Ackerman, 2021).

According to Zielke (2011), low prices can reduce negative emotions such as distress and anger by adding value. If negative emotions decrease, consumers' purchase intention may increase. In other words, positive emotions affect purchase intention positively. Some customers can feel embarrassment while buying from cheap retailers or think cheap prices might be caused by the unethical retail policy. In addition, customers can associate their own experiences with negative emotions such as excitement, unhappiness and anger related to certain retail prices. Customers' negative emotions affect their purchase intentions negatively. According to Ladhari et al. (2017), positive emotional satisfaction increased by service quality and service environment leads to a high recommendation, perceived high product quality, patronage intention and purchase intention. In her study conducted within the scope of factors affecting the purchasing decisions of consumers who shop online, Cinar (2020) found out consumers' positive emotions increase the frequency of shopping, while their negative emotions decrease this frequency. The hypotheses based on this conceptual information are as follows:

H8. Consumers' positive emotions toward supermarkets affect their purchase intention.

H9. Consumers' negative emotions toward supermarkets affect their purchase intention.

According to Hamilton and Chernev (2013), when consumers associate a price with stores with low prices, they consider them more negative compared to stores with high prices. In a sense, they relate the level of cheapness and quality in the opposite direction. However, living conditions and income inequalities lead consumers to search for cheap and quality products (Ceylan et al., 2016). Compared to alternative supermarkets, consumers think that they are shopping at more affordable prices and are satisfied with the price advantages offered, continuous shopping intentions, perceptions of value, high product and service quality

Consumers' price level 
EJMBE 31,1

\section{2}

perceptions are important significant indicators. By contrast, compared to alternative supermarkets, the perception of prices as expensive by consumers may be an indicator of their perception of the quality of goods and services (Duman and Yağc1, 2006). Therefore, it can be concluded that consumers' price level perception affects their emotions. The hypotheses created by synthesizing this conceptual knowledge in the literature are as follows:

H1O. Consumers' perception of cheapness affects their positive emotions toward supermarkets.

H11. Consumers' perception of cheapness affects their negative emotions toward supermarkets.

H12. Consumers' perception of expensiveness affects their positive emotions toward supermarkets.

H13. Consumers' perception of expensiveness affects their negative emotions toward supermarkets.

The results of the consumers' price level perception include reactions such as consumer beliefs and consumer behavior (Hamilton and Chernev, 2013). Emotions can affect both the result of a consumption experience and the evaluation of consumption experiences (Bagozzi et al., 1999). Individuals with negative emotions process information in more detail and make more accurate judgments by analyzing their external environment more accurately. Positive emotions can distract individuals because they concentrate on their positive thoughts, and they can give subliminal reactions while thinking more creatively (Forgas, 2013). In other words, if people are in a positive emotional state, they make consumption preferences suitable for a positive emotional state (Di Muro and Murray, 2012). Therefore, it can be assumed that any consumer who is sensitive to price will be prone to behaviorally purchasing when there are products that he/she finds affordable. His/her price level perception and emotions can mediate this relationship. Accordingly, the following hypotheses can be established as follows:

H14. Consumers' perception of cheapness mediates the relationship between their price sensitivity and purchase intention.

H15. Consumers' perception of expensiveness mediates the relationship between their price sensitivity and purchase intention.

H16. Consumers' positive emotions toward supermarkets mediate the relationship between their price sensitivity and purchase intention.

H17. Consumers' negative emotions toward supermarkets mediate the relationship between their price sensitivity and purchase intention.

Figure 1 shows the conceptual model of the research developed based on the theoretical background and literature. The hypotheses developed through synthesizing the literature have been presented below, and within the framework of this model, 17 hypotheses have been tested.

\section{Method}

\section{Measurements}

The data were collected through a questionnaire developed based on the literature. The four scales in the survey were from Graciola et al.'s (2018) study. There were five items on the price sensitivity scale and six items on the price level perception scale for supermarkets. On the 

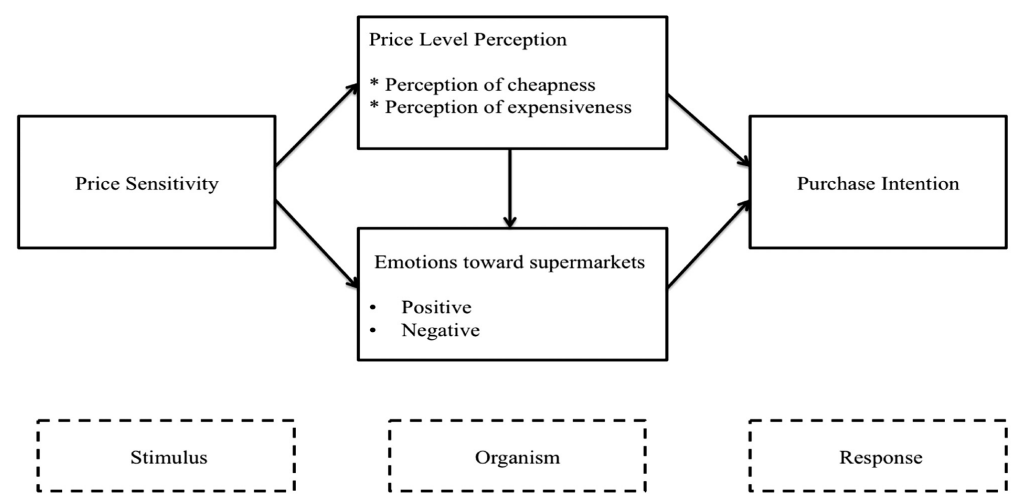

Figure 1. Conceptual model

emotion scale toward supermarket, there were 11 items, four of which were positive and seven of which were negative. The purchase intention scale had five items. The response categories of all items were subjected to the five-point Likert rating. The original items were in English. First, an English instructor, who has been doing a Ph.D. at the department of business administration, translated the scales' items into Turkish. Then, another English lecturer translated them into English again. There were not any semantic differences in scales' items when compared to the original versions.

\section{Sampling}

The population of the research was defined as the consumers aged 20-69 years. For the sampling framework, the consumers in the provincial center of Mersin were considered. Mersin is a port city located on Turkey's Mediterranean Coast. It has 13 counties. Mersin's Free Trade Zone, Turkey's second-largest one, has a prominent place in Mersin and country trade. Therefore, there are a lot of business centers and shipping and customs companies in Mersin. A lot of different kinds of fruits and vegetables are grown. Various souvenirs reflecting the local characteristics of Mersin are produced. It is possible to see beautiful examples of handicrafts in carpets, rugs, Mezitli cloth, various souvenirs made of banana fiber and colorful needle lace. Mersin cuisine including food, drinks and desserts is presented in each county of it. Mersin province is extremely rich in shopping centers. Various kinds of fruits, vegetables, clothes, food, drinks, desserts and souvenirs can be found and bought from these shopping centers (Mersin Provincial Directorate of Culture and Tourism, 2021).

We may explain why we selected to survey in Mersin. First, it is a metropolitan city. The second one is per capita income in Mersin is 8538 US\$, while it is 10,602 US\$ in Turkey (Turkish Statistical Institute, [TurkStat], 2019). Mersin has become 10th place through her per capita income among Turkey's 81 provinces. The third reason is that there are many brands of supermarkets such as Metro, CarrefourSA, Migros, BIM, A101 and Şok belonging to national and international supermarket chains, and Groseri, Ekorama, etc. belonging to local supermarket chains. The last one was the convenience of the data collection since the researchers were living in Mersin.

The survey was conducted in October and December 2018. The research sample was created by the quota sampling method, one of the nonprobabilistic sampling techniques. In the quota sampling method, subjects are appropriately selected from the targeted groups according to a predetermined number or quota. It is useful to use a particular group in situations where participation is critical (Sekaran and Bougie, 2016). The reason for preferring the quota-sampling method is that older consumers may be different from younger 
EJMBE 31,1

\section{4}

ones with regards to price sensitivity and purchasing intention. Gender and age quotas were determined. A total of 312,266 men and 321,622 women in 20-69 age groups have lived in Mersin's selected counties - Yenisehir, Akdeniz, Toroslar and Mezitli -through the end of December 2017. Because the study's population is $N>10,000$, the ideal sample size is 384 . But, the sample size was extended to 500 in order to form a sample of more or less 250 for each gender, and sample size of at least 30 for five age groups. These age groups were established depending on the age intervals obtained from the Turkish Statistical Institute. After calculations and rounding's made in the fractions, a sample size of 502 of which 255 were male and 247 female was determined. In the field study, 520 respondents were reached.

\section{Data analysis}

The data were analyzed in a two-step process just as Anderson and Gerbing (1988) suggested. As it was stated, at first, measurement quality was determined. For this purpose, the measures were subjected to reliability analysis and confirmatory factor analysis (CFA), which is utilized for testing how well the measurement variables represent the constructs (Hair et al., 2014). At this step, psychometric assessment via internal consistency reliability, convergent and discriminant validity were done. In the second step, the hypotheses were tested using the structural equation model (SEM). SEM, which is a multivariate technique using, especially, factor analysis and multiple regression analysis, provides knowledge on interrelated dependence relationships among measured variables and latent constructs (Hair et al., 2014). The normed chi-square, the root mean square error of approximation (RMSEA), the root mean square residual (RMR), standardized root mean residual (SRMR), comparative fit index (CFI), normed fit index (NFI) and nonnormed fit index (NNFI) were utilized to assess model fit for the measurement quality in CFA and structural models in SEM.

Before detecting measurement quality, the multivariate outliers were determined by calculating the Mahalanobis distances $\left(\mathrm{MD}^{2}\right.$ ). These distances transformed into $\mathrm{MD}^{2} / \mathrm{df}$ (Hair et al., 2014) and then the questionnaires having $\mathrm{MD}^{2}$, which exceeded the theoretical $t$-value at $\alpha$ : 0.001 , were deleted (Kalayci, 2006). In each of the price sensitivity and the purchase intention scale, there were five items, and $t$-value was 6.869 at $\alpha: 0.001$. The scale of emotions toward supermarkets had 11 items and $t$ value was 4.437 , and the price level perception scale had six items, having $t$-value was 5.959 . There were seven questionnaires that had $\mathrm{MD}^{2}$ exceeding the cut-off values, and those seven questionnaires were deleted. After deleting multivariate outliers, 513 questionnaires were retained for the analysis. In short, the study sample included 513 participants; 276 of which were male and 237 of which were female, which meant that the survey met the predetermined quotas.

It may be accepted that the sample size increased statistical power since the larger the sample size is, the greater precision in the test due to the less variation in the coefficients. CFA and SEM are required to have a large sample size, and it is highly advised to have 10-20 participants for each indicator variables, especially when robust estimation techniques, such as robust maximum likelihood, are used in case of the data had no multivariate normality (Kyriazos, 2018). Therefore, it was accepted that the sample size used was sufficient to conduct CFA and SEM and is larger than 500 - the minimum recommended sample size if the number of factors is larger than six (Hair et al., 2014) - which provided greater precision in test and increased statistical power.

Since there were four constructs (price sensitivity, price level perceptions, emotions toward supermarkets and purchase intention) that had interrelated dependence relationships, the data were at first subjected to CFA and then SEM. To run SEM, it is compulsory to provide multivariate normality. For this purpose, Mardia's Kappa test of multivariate normality was used. It was found that the chi-square value was significant $\left(\chi^{2}: 1459.6 ; p<0.001\right)$, showing evidence for not providing the multivariate normality. Therefore, robust maximum likelihood was used to predict the parameters. 


\section{Findings}

Profile of the respondents

Of the participants, $53.8 \%$ were women and $46.2 \%$ of them were men. Almost half of the sample was 20-39 year olds; the other half was 40-69 year olds. While $40 \%$ of the participants graduated from high school and below, approximately half of the participants had a bachelor's degree. Participants' monthly income was transformed into US\$, based on the exchange rate of Turkish Lira on the 1st of July 2018. A quarter of the sample's monthly income was about the minimum wage $-600 \$$. Nearly, half of the participants' monthly income was between $401 \$$ and $850 \$$ (Table 1).

\begin{tabular}{|c|c|c|c|c|c|c|}
\hline Variables & $n$ & $\%$ & Variables & $n$ & $\%$ & \\
\hline Gender & & & Level of education & & & \\
\hline Female & 276 & 53.8 & High school and below & 210 & 40.9 & \\
\hline \multirow{2}{*}{ Male } & 237 & 46.2 & Undergraduate & 268 & 52.2 & \\
\hline & & & Postgraduate & 35 & 6.8 & \\
\hline \multicolumn{3}{|c|}{ Income groups $1 \$: 4,10$ TL (July 1, 2018) } & Age groups & & & \\
\hline $400 \$$ and less & 128 & 25.0 & $20-29$ & 114 & 22.2 & \\
\hline $401-600 \$$ & 138 & 26.9 & 30-39 & 127 & 24.8 & Table 1. \\
\hline $601-850 \$$ & 106 & 20.7 & $40-49$ & 106 & 20.7 & Participants' \\
\hline $851-1200 \$$ & 94 & 18.3 & $50-59$ & 96 & 18.7 & demographic profile \\
\hline $1201 \$$ and more & 47 & 9.2 & $60-69$ & 70 & 13.6 & $(n: 513)$ \\
\hline
\end{tabular}

Consumers' price level

\section{Assessment of psychometric properties of measures}

At the first step, reliability of the scales was assessed via checking the minimum and the maximum corrected item-total correlations squared multiple correlations and Cronbach's alpha values (Table 2). There were four items in each of the dimensions -the perception of cheapness and positive emotions toward the supermarkets -, but one item from each was excluded since they had lower squared multiple correlations. Squared multiple correlations were preferred to be higher than 0.300 (Hair et al., 2014). While testing the measurement model, one item of the purchase intention scale was excluded to decrease the $\chi^{2} / \mathrm{df}$ fit statistics. As seen in Table 2, all the dimensions have sufficient composite reliability (CR) scores that was stated to be higher than 0.700 (Hair et al., 2014).

For controlling validity, CFA was conducted (Table 2). The CFA results yielded acceptable model fit statistics: $\left(\chi^{2}: 608.05\right.$; df: $237 ; p<0.0001 ; \chi^{2} /$ df: $2.56<3$; RMSEA: 0.055 ; (\%90 CI for RMSEA: 0.050-0.061); RMR: 0.067; SRMR: 0.047; CFI: 0.98: NFI: 0.96; NNFI: 0.97). A widely used goodness of fit (GOF) index is normed $\chi^{2}$. Calculated normed chi-square was lower than 3 and CFI was 0.98. Additionally, lower values than 0.08 of SRMR and lower values than 0.07 of RMSEA with higher values than $0.92 \mathrm{CFI}$ were assessed as the better fit provided. By taking account of the 0.96 value of the NFI and the 0.97 value of the NNFI provided extra evidence for model fit (Hair et al., 2014). Lower RMR, SRMR, RMSEA, normed chi-square with higher CFI, NFI and NNFI values represented a better fit of the model. It was also found that all of the standardized loadings were greater than 0.50 , and all $\mathrm{t}$-values were statistically significant at $5 \%$ significance level. Therefore, it is possible to say that construct validity was ensured.

For construct validity, the GOF statistics were evaluated. At first normed chi-square value was calculated as 2.56, just slightly below the cut-off point of 3 . The RMSEA was 0.055 , where RMSEA was required to be below 0.5 or 0.08 , and it was between 0.05 and 0.061 with $90 \%$ confidence. Besides RMSEA, RMR and SRMR were assessed, and it was found to be 0.067 and 0.047, respectively. The lower RMR and SRMR values, the better fit. For SRMR, it is 


\section{EJMBE 31,1}

Variables

Price sensitivity (PS); alpha: 0.82

I Buy as much as possible sale/discounted prices

Supermarkets with the lowest prices are usually my choice

I am willing to put in extra effort to find lower prices

I usually go and check the products and their prices in several supermarkets

before buying

Price is more important than the supermarket brand

Perception of cheapness (PC); alpha: 0.85

The price of this supermarket is very low

This is a cheap supermarket

The price of this supermarket is lower compared to other supermarkets

Perception of expensiveness (PE); alpha: 0.90

The price of this supermarket is very high

The price of this supermarket is expensive

Positive emotion (POE); alpha: 0.94

The price of this supermarket makes me feel happy

I am very satisfied with the price of supermarket

I like the price of this supermarket

Negative emotion (NEE); alpha: 0.93

The price of this supermarket makes me feel sad

I feel depressed when I think about the price of supermarket

I feel sad when I think about the price of supermarket

I feel angry when I think about the price of this supermarket

I am afraid to pay too much for the price of this supermarket

The price of this supermarket makes me feel unhappy

The price of this supermarket makes me angry

Purchase intention (PI); alpha: 0.88

I plan to do most of my future shopping in this supermarket

If I go shopping today, I will go to this supermarket again

I do most of my shopping in this supermarket

When I go shopping, I consider this supermarket first
St.values $t$-values Error

AVE: 0.49; CR: 0.86

$0.61 \quad 14.27 \quad 0.62$

$0.70 \quad 16.77 \quad 0.52$

$\begin{array}{lll}0.80 & 20.35 & 0.36\end{array}$

$\begin{array}{lll}0.76 & 18.89 & 0.42\end{array}$

$0.62 \quad 14.44 \quad 0.62$

AVE: 0.67; CR:0.86

$\begin{array}{lll}0.85 & 22.63 \quad 0.27\end{array}$

$\begin{array}{lll}0.90 & 24.53 \quad 0.18\end{array}$

$0.69 \quad 17.04 \quad 0.52$

AVE: 0.83; CR: 0.91

$\begin{array}{lll}0.87 & 22.11 & 0.24\end{array}$

$0.96 \quad 24.61 \quad 0.11$

AVE: 0.75; CR: 0.90

$0.82 \quad 22.04 \quad 0.32$

$\begin{array}{lll}0.92 & 25.98 & 0.16\end{array}$

$0.85 \quad 23.11 \quad 0.28$

AVE: 0.66; CR: 0.96

$\begin{array}{lll}0.75 & 19.68 & 0.43\end{array}$

$\begin{array}{lll}0.74 & 19.11 & 0.46\end{array}$

$\begin{array}{lll}0.85 & 23.63 \quad 0.28\end{array}$

$\begin{array}{lll}0.84 & 23.23 & 0.29\end{array}$

$\begin{array}{lll}0.74 & 19.32 & 0.45\end{array}$

$\begin{array}{lll}0.89 & 25.34 & 0.21\end{array}$

$0.86 \quad 24.32 \quad 0.25$

AVE: 0.64; CR: 0.88

$\begin{array}{lll}0.77 & 19.86 & 0.40\end{array}$

$\begin{array}{lll}0.87 & 23.76 & 0.24\end{array}$

$\begin{array}{lll}0.74 & 18.87 & 0.45\end{array}$

$0.82 \quad 21.56 \quad 0.33$
Table 2.

The results of CFA

Note(s): $\chi^{2}: 608.05$; df: $237 ; p<0.0001 ; \chi^{2} /$ df: $2.56<3$; RMSEA: 0.055; RMR: 0.067; SRMR: 0.047; CFI: 0.98: NFI: 0.96 and NNFI: 0.97

recommended to be lower than 0.10 (Hair et al., 2014). In our large sample $(n>500)$ with 24 indicator variables in total, SRMR is advised to be less than 0.08 with a higher CFI value exceeding 0.92. In our case, SRMR is 0.047 and CFI is 0.98 . It is said that CFI values above 0.90 are usually associated with a model that fits well. To explain validity better, in addition to CFI, NFI and NNFI were reported as incremental fit indices. They were found to be 0.96 and 0.97, respectively, where the higher values indicate better fit (Hair et al., 2014). By taking into account the GOF statistics reported, it could easily be said that some strong evidence were found for construct validity.

To explain the validity better, convergent and discriminant validity was examined. The average variance extracted (AVE) formed by price sensitivity was 0.49 . The AVE of PC and PE were 0.67 and 0.83 respectively, while AVE for POE toward supermarkets was 0.75 and for NEE was 0.66. AVE of PI was calculated as 0.64. It was assessed that significant loadings, model-fit-statistics and AVE by latent variables showed sufficient evidence for the convergent validity (Anderson and Gerbing, 1988; Fornell and Larcker, 1981).

For discriminant validity; the maximum shared variances (MSVs), the average shared variances (ASVs) and AVE values were assessed. It was found that MSVs and the ASVs for all dimensions were less than their respective AVE values. Therefore, it was accepted discriminant validity was provided (Hair et al., 2014). Additionally, the square roots of the 
AVE value for all of the dimensions were assessed. It was supported that if they were greater than shared coefficients of correlations, they provide additional evidence for the factors' discriminant validity (Hair et al., 2014) (Table 3).

For reliability, additional checks were done through the CFA results. $\mathrm{CR}$ values calculated from CFA results and correlations among the dimensions were evaluated (Tables 2 and 3 ). All CR were greater than 0.700 (Hair et al., 2014). All the AVE values were found to be greater than the shared correlation coefficients of the factors. Therefore, it means that all measures' reliabilities were ensured (Bagozzi and Yi, 1988).

\section{Hypothesis testing}

In the present study, 17 hypotheses were suggested. These hypotheses were tested using SEM) with robust maximum likelihood. After CFA, SEM produced acceptable fit statistics: $\left(\chi^{2}\right.$ : 584.56; df: $239 ; p<0.0001 ; \chi^{2} /$ df: $2.45<3$; RMSEA: 0.062 (\%90 CI for RMSEA: 0.057-0.068); RMR: 0.13; SRMR: 0.09; CFI: 0.96: NFI: 0.93; NNFI: 0.95). SRMR statistics were found to be 0.09 , slightly greater than the common cut-off points of 0.08 when the number of observed variables were between 12 and 30 and the sample size was bigger than 250 (Hair et al., 2014, p. 584). However, lower normed chi-square and RMSEA values with higher CFI, NFI and NNFI ensured evidence for acceptable model fit (Hair et al., 2014).

As it might be seen from Figure 2 and Table 4, except for three of 13 hypotheses related to direct ways, all $t$-values are greater than 1.96 , which is the cut-off point at $\alpha: 0.05$ level significant. The $t$-value of $\mathrm{H} 6$ (the way from PC to PI) is $1.958 ; p: 0.05$, just being at the cut-off points; thus, it requires being cautious. Therefore, it could be claimed that ten hypothesized relations were supported.

The main hypothesis (H1) that consumers' price sensitivity affects their purchase intention $(\beta$ : 0.17) was supported. Our argument was built on that PS had the impacts on PC and PE. While PS had a positive impact on $\mathrm{PC}(\beta$ : 0.29) (H2), it did not affect $\mathrm{PE}(\beta$ : -0.08$)(\mathrm{H} 3)$. Another investigation was on that PS might affect the emotions toward the supermarkets. SEM showed that PS had no impact on POE $(\beta$ : -0.03$)(\mathrm{H} 4)$, but impacted NEE $(\beta$ : -0.37$)$ negatively (H5).

In our argument, there were two mediator variables, each of which had two dimensions. One of them was the price level perception; it had two factors, namely $\mathrm{PC}$ and $\mathrm{PE}$. Hypothesized relations claiming $\mathrm{PC}(\mathrm{H} 6 \rightarrow \beta: 0.12)$ and $\mathrm{PE}(\mathrm{H} 7 \rightarrow \beta:-0.16)$ had impacted the PI were evidenced by the data. For the dimensions of second mediator variable, it was found that POE toward the supermarkets had influenced PI $(\beta$ : 0.34) (H8), while NEE toward the supermarkets had no impact on PI $(\beta$ : -0.05$)(\mathrm{H} 9)$.

In the study, there were additional inquiries on the issue of how price level perception of supermarkets influenced the emotions toward the supermarkets. It was determined that PC

\begin{tabular}{lccccccccccr}
\hline & $\bar{x}$ & SD & MSV & ASV & CR & PS & PC & PE & POE & NEE & PI \\
\hline PS & 3.21 & 0.99 & 0.09 & 0.05 & 0.86 & $(0.70)$ & & & & & \\
PC & 2.68 & 0.99 & 0.14 & 0.09 & 0.86 & $0.31^{* *}$ & $(0.82)$ & & & & \\
PE & 3.33 & 1.10 & 0.24 & 0.9 & 0.91 & $-0.10^{*}$ & $0.32^{* *}$ & $(0.91)$ & & & \\
POE & 2.95 & 1.05 & 0.18 & 0.10 & 0.90 & 0.08 & $-0.38^{* *}$ & $0.31^{* *}$ & $(0.87)$ & & \\
NEE & 3.59 & 1.04 & 0.24 & 0.11 & 0.96 & $-0.30^{* *}$ & $-0.21^{* *}$ & $0.49^{* *}$ & $0.43^{* *}$ & $(0.81)$ & \\
PI & 3.46 & 0.87 & 0.10 & 0.04 & 0.88 & $0.26^{* *}$ & $-0.24^{* *}$ & -0.04 & $0.31^{* *}$ & -0.02 & $(0.80)$
\end{tabular}

Note(s): PS: Price sensitivity, PC: Perception of cheapness and PE: Perception of expensiveness

POE: Positive emotions, NEE: Negative emotions, PI: Purchase intention

SD: Standard deviation. The numbers in the cells of diagonal line are squared root of AVE

**. Correlation is significant at the 0.01 level (two-tailed)

*. Correlation is significant at the 0.05 level (two-tailed)

Consumers' price level

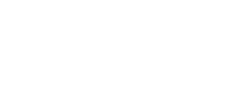




\section{EJMBE 31,1}

\section{8}

Figure 2.

Model testing through SEM

Table 4.

Path estimates of structural models
Note(s): Chi-Square $=584.56, \mathrm{df}=239, \mathrm{P}$-value $=0.00000$, RMSEA $=0.062$

\begin{tabular}{|c|c|c|c|c|}
\hline & Relationship & Standardized path coefficients & $t$-values & Result \\
\hline $\mathrm{H} 1$ & $\mathrm{PS} \rightarrow \mathrm{PI}$ & 0.17 & 3.03 & Supported \\
\hline $\mathrm{H} 2$ & $\mathrm{PS} \rightarrow \mathrm{PC}$ & 0.29 & 5.76 & Supported \\
\hline $\mathrm{H} 3$ & $\mathrm{PS} \rightarrow \mathrm{PE}$ & -0.08 & -1.68 & Not supported \\
\hline $\mathrm{H} 4$ & $\mathrm{PS} \rightarrow \mathrm{POE}$ & -0.03 & -0.66 & Not supported \\
\hline $\mathrm{H} 5$ & $\mathrm{PS} \rightarrow \mathrm{NEE}$ & -0.37 & -7.83 & Supported \\
\hline H6 & $\mathrm{PC} \rightarrow \mathrm{PI}$ & 0.12 & 2.25 & Supported \\
\hline $\mathrm{H} 7$ & $\mathrm{PE} \rightarrow \mathrm{PI}$ & -0.16 & -2.79 & Supported \\
\hline H8 & $\mathrm{POE} \rightarrow \mathrm{PI}$ & 0.34 & 6.36 & Supported \\
\hline $\mathrm{H} 9$ & $\mathrm{NEE} \rightarrow \mathrm{PI}$ & -0.05 & -0.86 & Not supported \\
\hline $\mathrm{H} 10$ & $\mathrm{PC} \rightarrow \mathrm{POE}$ & 0.37 & 7.40 & Supported \\
\hline H11 & $\mathrm{PC} \rightarrow \mathrm{NEE}$ & 0.24 & 5.46 & Supported \\
\hline $\mathrm{H} 12$ & $\mathrm{PE} \rightarrow \mathrm{POE}$ & 0.25 & 2.25 & Supported \\
\hline $\mathrm{H} 13$ & $\mathrm{PE} \rightarrow \mathrm{NEE}$ & 0.46 & 9.97 & Supported \\
\hline
\end{tabular}

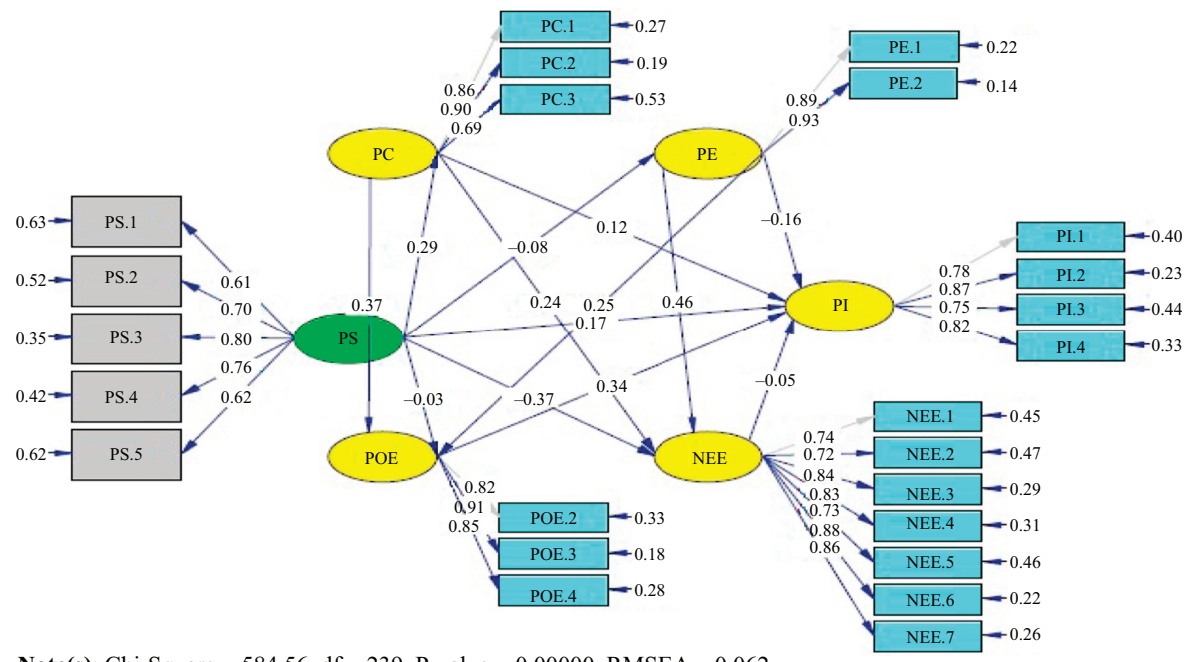

Note(s): $\chi^{2}: 6584.56$; df: $239 ; p<0.0001 ; \chi^{2} /$ df: $2.44<3$; RMSEA: 0.062 (\%90 CI for RMSEA: 0.057-0.068); RMR: 0.013; SRMR: 0.09; CFI: 0.96: NFI: 0.93; NNFI: 0.95

PS: Price sensitivity, PC: Perception of cheapness and PE: Perception of expensiveness POE: Positive emotions, NEE: Negative emotions and PI: purchase intention

and $\mathrm{PE}$ had impacted POE $(\mathrm{H} 10 \rightarrow \beta: 0.37 ; \mathrm{H} 12 \rightarrow \beta: 0.25)$ and $\mathrm{NEE}(\mathrm{H} 11 \rightarrow \beta: 0.24 ; \mathrm{H} 13 \rightarrow \beta$ : $0.46)$ positively.

Utilizing the path coefficients of variables on PI, the regression formula can be written as follows. It was determined that one unit increase in POE resulted in 0.340 units in PI, and NEE had no statistically significant impact on PI. While one unit increase in PC increased PI 0.124 and PE decreased 0.155 units in PI. On the one hand one, unit increase in PS resulted with an increase 0.170 in PI. It has been found that the model predicted $22 \%$ of the variation in PI. If $R^{2}$ has a minimum of 0.04 , it might be interpreted from the practical; if it has a minimum of 0.25 , it may be accepted as the moderate effect (Ferguson, 2009). Although it is very near to moderate effect, the results of the model should be commented from the practical perspective. 
$\mathrm{PI}=0.170 \times \mathrm{PS}+0.124 \times \mathrm{PC}-0.155 \times \mathrm{PE}+0.340 \times \mathrm{POE}-0.0509 \times \mathrm{NEE}\left(R^{2}: 0.221\right)$

In our conceptual framework, there were four mediation-related hypotheses. These hypotheses were indicating that there were mediation roles of price level perception and emotions toward supermarkets between the price sensitivity and the purchase intention. Each mediation-related hypothesis was separately tested via SEM, and results were presented in Table 4. For mediation tests, the direct way and all indirect ways should be statistically significant (Baron and Kenney, 1986). It was found that PS had a statistically significant impact on PI ( $\beta$ : 0.17). For the first mediation (H14), all conditions were satisfied. However, for the rest (H15; H16 and H17), one of the conditions was not met, resulting in not executing the mediation test. The last condition can be satisfied if the parameter estimate between price sensitivity and purchase intention becomes insignificant (full mediation) or less significant (partial mediation) than the parameter estimate in a direct way.

The hypothesis (H14: Consumers' perception of cheapness mediates the relationship between their price sensitivity and purchase intention) was supported by the data. The direct impact of PS was $\beta: 0.27$, but when analyzed with adding $\mathrm{PC}$ into the model, it decreased to $\beta$ : 0.21 , and it was still significant, indicating the partial mediation. The indirect effect is weaker than the direct effect. Therefore, it was determined that PC of supermarkets had partially decreased the impact of PS on PI.

\section{Discussion}

The present study is based on Mehrabian and Russell's (1974) SOR model. The direct and indirect relations among price sensitivity (dependent variable), price level perception (mediator), emotions (mediator) and purchase intention were investigated within the scope of supermarkets. In other words, the impact of price sensitivity on price level perception, emotions and purchase intention; the impact of price level perception on emotions and purchase intention and the impact of emotions on purchase intention were examined. In addition, the mediating effect of price level perception and emotions between price sensitivity and purchase intention was examined. The results of the study are discussed in terms of three basic subjects: scales, model and hypotheses.

In terms of scales, it was determined that the variables - consumers' price sensitivity, emotions toward supermarkets and purchase intention - examined in the study were loaded to the correct dimensions as in the original scales (Noyan and Şimşek, 2012; Graciola et al., 2018). Yet, one-dimensional price level perception scale was loaded into two dimensions called as perception of cheapness and perception of expensiveness. The results of the analysis supported the data obtained through four scales are quite reliable and valid. Thus, it can be concluded that these four scales are effective within the different contexts of research and provide reliable and valid results. The measurement tool has measured the structure it aims to measure and the properties related to this structure following the purpose.

It can be said that consumers tend to make extra efforts to purchase low-priced products. By examining the prices of products in different supermarkets, consumers shop at supermarkets where low-priced products are sold. For this reason, consumers are generally satisfied with the product prices of the supermarkets they shop for. In addition, consumers' perception of product prices in different supermarkets as cheap or expensive shows that they can distinguish the price differences between the supermarkets. Consumers tend to buy products from a supermarket where they usually shop.

As it was stated in the introduction and theoretical framework and research hypotheses, different research studies (Chang et al., 2011; Viera, 2013; Hetharie et al., 2019; Laato et al., 2020) have adopted the SOR model in their own context by integrating cognitive and affective factors into the model. The present study provides an adequate theoretical framework to

Consumers' price level 
EJMBE 31,1 explain consumers' behavior by including price sensitivity as a stimulus, price level perception and emotions as organism and purchase intention as a response.

In total, 10 of the 13 research hypotheses developed to examine direct relations between the variables were supported, but three of which were not supported by the data. The result of the study supports the conclusion that the price sensitivity is effective in purchase intention obtained through studies conducted by Noh et al. (2013), Chua et al. (2015), Uslu and Huseynli (2018), Ghali-Zinouhi and Toukabri (2019) and Walia et al. (2020). Oppose to the findings of Backman and Crompton (1991), it was found that consumers' price sensitivity does not affect their perception of expensiveness toward supermarkets but affects their perception of cheapness. There are many supermarkets offering similar products at different prices. Consumers choose the most affordable one for them by comparing supermarkets with each other. In short, consumers, who are sensitive to price, may think that the products' price is not cheap. Consumers, with low price sensitivity, may think that the products' price is not expensive.

When the direct relation between price sensitivity and emotions was examined, it was that price sensitivity was influential on negative emotions but not on positive emotions. Consumers' price sensitivity affects their negative emotions positively. In other words, it turns negative emotions into positive ones. However, price sensitivity does not change positive emotions toward supermarkets. The main reason for this may be the fact that consumers prefer supermarkets where they are satisfied with the product prices and where they usually shop. As Yao and Oppewal (2016) and Fecher et al. (2019) stated, the other reason might be that the price presentation (unit price or retail price), size and package lead consumers to satisfy and continue to buy goods by controlling the impact of consumers' price sensitivity on positive emotions. The result of the study supports the conclusion that consumers' price level perception, both perception of expensiveness and perception of cheapness, is effective in purchase intention obtained through studies conducted by Duman and Yağc1 (2006), Hamilton and Chernev (2013) and Fecher et al. (2019).

While positive emotions are influential in consumers' purchase intention, negative emotions are not effective in consumers' purchase intention. This result supports the results obtained through the studies conducted by Zielke (2011), Ladhari et al. (2017) and Cinar (2020). Through different effective pricing strategies or other strategies such as sales promotions, effective advertising positive emotions can be improved, and negative emotions can be decreased. Thus, this leads to more frequent purchases.

Each dimension of price level perception affects both consumers' positive emotions and negative emotions toward supermarkets. This finding supports the finding of Duman and Yağc1 (2006), Hamilton and Chernev (2013) and Ceylan et al. (2016). Consumers assume price level is an indicator of the quality of supermarkets and their goods and services. Thus, when they think they buy affordable good-quality goods, they are satisfied and express positive emotions. In conclusion, it can be said that consumers' price level perception regarding supermarkets affects their emotions toward supermarkets positively.

One of the four research hypotheses developed to examine mediating relations between the variables was supported, but three of which were not supported by the data. The present study established evidence for partial mediation. Consumers' perception of cheapness partially decreased the impact of price sensitivity on purchase intention. Consumers usually try to maximize their benefits when they buy products. Thus, the price has an influential role in the purchasing process. Consumers subconsciously consider price levels of certain product types more than others. If frequently bought products, products needed more or such infrequently purchased products leading to the purchase of complementary products are at affordable prices, even price sensitive consumers will perceive the price level of these products as low and buy them or remember its price comparing to other supermarkets. In this context, although consumers' price sensitivity influences their purchase intention, consumers' perception of 
cheapness in relation to the prices they see in the supermarkets where they shop at is also effective on purchase intention, even reducing the effect of price sensitivity alone.

\section{Theoretical implications}

First, the academic significance of this study lies in the modification of the SOR model. Various studies in retailing modified the SOR model, but the results are not consistent and general models have not been proposed. The present study modified the SOR model using variables price sensitivity, price level perception, emotions toward supermarkets and purchase intention. It illustrates the SOR model is an adequate theoretical model to explain consumers' behavior and thus contributes to the marketing literature since its main focus is the factors affecting consumers' purchase intention.

Second, this study examines the factors affecting consumers' purchase intention within the scope of supermarkets. In the literature, it was suggested that retail brand reputation should be examined with regards to price sensitivity and the impact of negative emotions on price image in both lower and higher level stores (Graciola et al., 2018). Thus, the effects of consumers' price sensitivity on their price perception, emotions toward supermarkets and purchase intention were examined. The study also examined the effects of consumers' price perception and emotions toward supermarkets on purchase intention. The results obtained related to the influence of price sensitivity on purchase intention; price sensitivity on the perception of cheapness; sensitivity on negative emotions; both perception of cheapness and expensiveness on purchase intention; positive emotions on purchase intention and both perception of cheapness and expensiveness on positive and negative emotions supported the previous studies (Backman and Crompton, 1991; Duman and Yağc1, 2006; Zielke, 2011; Noh et al., 2013; Hamilton and Chernev, 2013; Chua et al., 2015; Yao and Oppewal, 2016; Ladhari et al., 2017; Uslu and Huseynli, 2018; Graciola et al., 2018; Fecher et al., 2019; Ghali-Zinoubi and Toukabri, 2019; Cinar, 2020 and Walia et al., 2020). Oppose to the previous studies, it was found that price sensitivity did not affect the perception of expensiveness and positive emotions. Besides, negative emotions were not effective on purchase intention. In these respects, the study makes a major contribution to the literature. These findings can be supported by similar results obtained through different future studies. It can be examined why negative emotions do not change the purchase intention negatively or positively. Similarly, it can be investigated why price sensitivity is not effective on positive emotions or perception of expensiveness. By including variables such as pricing strategies (unit pricing, retail pricing, etc.), size and package of goods, distance to the supermarket and the atmosphere in the supermarkets, it can be examined whether similar or different results can be obtained.

Third, this study examines the sufficient mediating impacts of consumers' price perception and emotions toward supermarkets between price sensitivity and purchase intention. Since the previous studies (Duman and Yağc1, 2006; Hamilton and Chernev, 2013; Fecher et al., 2019) based on the direct effects of price level perception, the present study provides evidence for partial mediation of consumers' perception of cheapness. This leads to an area of research related to the mediation effects of price level perception and its causes.

\section{Practical implications}

The way consumers process information and their familiarity with supermarket prices have an impact on their PS. Consumers' price level perception and emotions toward supermarkets will affect consumers' PI weakly or strongly depending on their PS. Understanding how price level perception changes over time helps retail managers better understand changes in consumers' behavior. Determining the impact of consumers' price sensitivity, price level perception and emotions toward supermarkets can lead supermarket managers to understand the behavioral changes and consumers' perceptions and to offer affordable products that can affect consumers' purchasing behavior by developing pricing strategies.

Consumers' price level 
EJMBE 31,1

\section{2}

Retailers should give more importance to the price level that reflects whether the store is cheap or expensive according to customers.

Creating pricing strategies has become difficult in a changing economy and technological environment. Today, various competitive companies have been providing similar products. They decide on prices considering differences in geographical demands, costs, market segmentation needs, purchasing time, levels of orders and other factors such as lower market share, economic stagnation and cost inflation. Depending on these changing conditions, they can change prices. But companies should carefully manage consumer perceptions when they increase or decrease prices. They should position the price correctly in order to make consumers think that the prices seen on the shelves or price lists at an appropriate level and ultimately buy it. When positioning price, the cost of the product, whether the price reflects the value of the product, whether it is suitable for the target consumers, the price levels of rival enterprises, discount terms, additional products or services and whether the predicted price is perceived by consumers easily should be investigated.

Consumers who find the price level high do not buy the product without trying it or knowing its features and may buy another product or brand. When determining the price, companies can apply psychological pricing considering that showing the price level lower than the actual level it is, can affect consumers' purchasing decision and encourage their purchase. Various pricing policies such as discount pricing, segmented pricing, fixed pricing and promotional pricing can be preferred depending on the product and its features. In order to attract more consumers to supermarkets and increase consumers' shopping frequency and quantity, reasonably priced goods and services that affect consumers' perceptions, attitudes and emotions and that satisfy them.

In order to be preferred by consumers and achieve a competitive advantage over others, retailers should focus on consumers' perceptions and emotions. They should aim to develop positive emotions and better perceptions leading to purchase intention. In order to achieve this aim, they should determine consumers' needs, desires and wants, depending on these facts they should create an effective marketing strategy and position products. In addition, they should develop a relationship between the products features offered and consumers' emotions. In short, retailers should get consumers' attention and leave a mark on them to create loyal and satisfied consumers. Therefore, it is assumed that this study provides practical evidence for retailers.

\section{Limitations and future research}

The main limitation of this research is the distance to supermarkets; in other words, supermarkets' closeness to consumers has been ignored. Consumers who are less sensitive to price prefer closest stores, frozen food and home delivery; even if the price is too high, they perceive time and effort more costly (Zeithaml, 1988). The research examined consumers' emotions toward supermarkets on their purchase intention, focusing only on the price sensitivity and the price level in supermarkets. In addition to price, consumers consider criteria such as the location of the supermarket, product line depth and width, advertisement and sales development, services provided and employees (Engel et al., 1990). Ignoring other factors that consumers consider when choosing a supermarket is another limitation of the research. In future studies, research topics can be developed by adding nonprice factors to model. The SOR model can be tested including the location of supermarket, product line depth and width, advertisement and sales development, services provided and employees into the model in future studies.

Collecting data by quota sampling is another limitation of this research since quotas were determined through sex and age group ratios. Since the research data were not collected considering individuals' income levels, the income levels of the participants in the sample may be similar. Therefore, it cannot be determined whether consumers' behavior regarding price 
and purchase intention differs depending on their income status. If data collected through quota sampling considered individuals' income levels, different findings might be obtained.
Consumers' price level

\section{References}

Ackerman, C.E. (2021), "What are positive and negative emotions and do we need both?", Positive Psychology.com, available at: https://positivepsychology.com/positive-negative-emotions/ (accessed 29 January 2021).

Anderson, J.C. and Gerbing, D.W. (1988), "Structural equation modeling in practice: a review and recommended two-step approach”, Psychological Bulletin, Vol. 103 No. 3, pp. 411-423, doi: 10. 1037/0033-2909.103.3.411.

American Psychological Association [APA] (2020), "Emotion", available at: https:/dictionary.apa.org/ emotion.

Backman, S.J. and Crompton, J.L. (1991), "The usefulness of selected variables for predicting activity loyalty”, Leisure Sciences, Vol. 13 No. 3, pp. 205-220, doi: 10.1080/01490409109513138.

Bagozzi, R.P. and Yi, Y. (1988), "On the evaluation of structural equation models", Journal of the Academy of Marketing Science, Vol. 16 No. 1, pp. 74-94, doi: 10.1007/BF02723327.

Bagozzi, R., Gopinath, M. and Nyer, P. (1999), "The role of emotions in marketing”, Journal of Academy of Marketing Science, Vol. 27 No. 2, pp. 184-206, doi: 10.1177/0092070399272005.

Baron, R.M. and Kenny, D.A. (1986), "The moderator-mediator variable distinction in social psychological research: conceptual, strategic and statistical considerations", Journal of Personality and Social Psychology, Vol. 51 No. 6, pp. 1173-1182, doi: 10.1037//0022-3514.51.6.1173.

Boonpattarakan, A. (2012), "An experimental design to test the main and interaction effects of CSR involvement, brand naming and pricing on purchase intentions in Thailand", International Journal of Business and Management, Vol. 7 No. 16, pp. 62-79, doi: 10.5539/ijbm.v7n16p62.

Ceylan, H.H., Aydın, M. and Altıntop, M.Y. (2016), "Tüketicilerin pazarlık eğilimini etkileyen faktörlerin yapısal eşitlik modellemesi ile incelenmesi (Analyzing the factors affecting bargaining tendency of consumers through structural equation modeling)", Scientific Cooperation for the Future in the Social Sciences International Conference-2016.

Chang, H., Eckman, M. and Yan, R. (2011), "Application of the stimulus-organism-response model to the retail environment: the role of hedonic motivation in impulse buying behavior", The International Review of Retail, Distribution and Consumer Research, Vol. 21 No. 3, pp. 233-249, doi: 10.1080/09593969.2011.578798.

Chua, B.L., Lee, S., Goh, B. and Han, H. (2015), "Impacts of cruise service quality and price on vacationers cruise experience: moderating role of price sensitivity", International Journal of Hospitality Management, Vol. 44, pp. 131-145, doi: 10.1016/j.ijhm.2014.10.012.

Cinar, D. (2020), "Chapter 11. The effects of consumer emotions on online purchasing behavior", in Meral, Y. (Ed.), Tools and Techniques for Implementing International E-Trading Tactics for Competitive Advantage, IGI Global. doi: 10.4018/978-1-7998-0035-4.ch011.

Clow, K.E. and Baack, D. (2016), Integrated Advertising, Promotion, and Marketing Communications, 7th ed., Pearson Education, Harlow.

Di Muro, F. and Murray, K.B. (2012), "An arousal regulation explanation of mood effects on consumer choice”, Journal of Consumer Research, Vol. 39 No. 3, pp. 574-584, doi: 10.1086/664040.

Donovan, R.J. and Rossiter, J.R. (1982), "Store atmosphere: an environmental psychology approach", Journal of Retailing, Vol. 58 No. 1, pp. 34-57.

Duman, T. and Yağcl, M.I. (2006), "On factors affecting continuous purchase intentions of supermarket customers: an attempt at modeling”, METU Studies in Development, Vol. 33 No. 1, pp. 87-116.

Emir, A., Halim, H., Hedre, A., Abdullah, D., Azmi, A. and Kamal, S.B.M. (2016), "Factors influencing online hotel booking intention: a conceptual framework from stimulus-organism-response 
EJMBE 31,1

perspective", International Academic Research Journal of Business and Technology, Vol. 2 No. 2 , pp. 129-134.

Engel, J.F., Blackwell, R.D. and Miniard, P.W. (1990), Consumer Behaviour, 10th ed., The Dryden Press, Chicago.

Fecher, A., Robbert, T. and Roth, S. (2019), "Same price, different perception: measurement-unit effects on price-level perceptions and purchase intentions", Journal of Retailing and Consumer Services, Vol. 49 No. 2019, pp. 129-142, doi: 10.1016/j.jretconser.2019.03.017.

Ferguson, C.J. (2009), “An effect size primer: a guide for clinicians and researchers”, Professional Psychology: Research and Practice, Vol. 40 No. 5, pp. 532-538, doi: 10.1037/a0015808.

Forgas, J.P. (2013), "Don't worry, be sad! on the cognitive, motivational, and interpersonal benefits of negative mood", Current Directions in Psychological Science, Vol. 22 No. 3, pp. 225-232, doi: 10. 1177/0963721412474458.

Fornell, C. and Larcker, D.F. (1981), "Evaluating structural equation models with unobservable variables and measurement error", Journal of Marketing Research, Vol. 18 No. 1, pp. 39-50, doi: $10.2307 / 3151312$.

Ghali-Zinoubi, Z. and Toukabri, M. (2019), "The antecedents of the consumer purchase intention: sensitivity to price and involvement in organic product: moderating role of product regional identity", Trends in Food Science and Technology, Vol. 90 No. 2019, pp. 175-179, doi: 10.1016/j. tifs.2019.02.028.

Goi, M.T., Kalidas, V. and Zeeshan, M. (2014), “Comparison of stimulus-organism-response framework between international and local retailer", Procedia-Social and Behavioral Sciences, Vol. 130 No. 2014, pp. 461-468, doi: 10.1016/j.sbspro.2014.04.054.

Graciola, A.P., de Toni, D., de Lima, V.Z. and Milan, G.S. (2018), "Does price sensitivity and price level influence store price image and repurchase intention in retail markets?", Journal of Retailing and Consumer Services, Vol. 44, pp. 201-213, doi: 10.1016/j.jretconser.2018.06.014.

Hair, J.F., Black, W.C., Babin, J.B. and Anderson, R.E. (2014), Multivariate Data Analysis, 7th ed., Pearson Education, Harlow.

Hamilton, R. and Chernev, A. (2013), "Low prices are just the beginning: price image in retail management”, Journal of Marketing, Vol. 77, pp. 1-20, doi: 10.1509/jm.08.0204.

Han, J., Gupta, S. and Lehmann, D.R. (2001), "Consumer price sensitivity and price thresholds", Journal of Retail, Vol. 77 No. 4, pp. 435-456, doi: 10.1016/S0022-4359(01)00057-4.

Hanaysha, J.R. (2018), "An examination of the factors affecting consumer's purchase decision in the Malaysian retail market”, PSU Research Review, Vol. 2 No. 1, pp. 7-23, doi: 10.1108/PRR-082017-0034.

Heda, S., Mewborn, S. and Caine, S. (2017), "How customers perceive a price is as important as the price itself", Harward Business Review, available at: https://hbr.org/2017/01/how-customersperceive-a-price-is-as-important-as-the-price-itself (accessed 3 January 2017).

Hetharie, J.A., Surachman Hussein, A.S. and Puspaningrum, A. (2019), "SOR (stimulus-organismresponse) model application in observing the influence of impulsive buying on consumer's postpurchase regret", International Journal of Scientific and Technology Research, Vol. 8 No. 11, pp. 2829-2841.

Hoch, S.J., Kim, B., Montgomery, A.L. and Rossi, P.E. (1995), "Determinants of store-level price elasticity", Journal of Marketing Research, Vol. 32, pp. 17-29, doi: 10.2307/3152107.

Islam, J.U. and Rahman, Z. (2017), "The impact of online brand community characteristics on customer engagement: an application of stimulus-organism-response paradigm", Telematics and Informatics, Vol. 34 No. 2017, pp. 96-109, doi: 10.1016/j.tele.2017.01.004.

Kagan, J. (2020), "Price sensitivity”, Investopedia, available at: https:/www.investopedia.com/terms/p/ price-sensitivity.asp (accessed 22 November 2020).

Kalayci, Ş. (2006), SPSS Uygulamah Çok Değişkenli İstatistik Teknikler (SPSS Applied Multivariate Statistical Techniques), Asil yayınc1lik, Ankara. 
Kim, Y.K., Lee, M.Y. and Park, S. (2016), "Shopping value orientation: conceptualization and measurement”, Journal of Business Research, Vol. 67 No. 1, pp. 2884-2890, doi: 10.1016/j.jbusres. 2012.06.006.

Kim, M.J., Lee, C. and Jung, T. (2018), "Exploring consumer behaviour in virtual reality tourism using an extended stimulus-organism-response model", Journal of Travel Research, Vol. 59 No. 1, pp. 1-21, doi: 10.1177/0047287518818915.

Kotler, P. and Armstrong, G. (2012), Principles of Marketing, 14th ed., Pearson Education, Essex.

Kotler, P. and Keller, K.L. (2012), Marketing Managament, 14th ed., Pearson Education, Prentice Hall, New Jersey, NJ.

Kyriazos, T.A. (2018), "Applied psychometrics: sample size and sample power considerations in factor Analysis (EFA, CFA) and SEM in general”, Psychology, Vol. 9, pp. 2207-2230, doi: 10.4236/ psych.2018.98126.

Laato, S., Islam, A.K.M.N., Farooq, A. and Dhir, A. (2020), "Unusual purchasing behavior during the early stages of the COVID-19 pandemic: the stimulus-organism-response approach", Journal of Retailing and Consumer Services, Vol. 57 No. 2020, pp. 1-12, doi: 10.1016/j.jretconser.2020.102224.

Ladhari, R., Souiden, N. and Dufour, B. (2017), "The role of emotions in utilitarian service settings: the effects of emotional satisfaction on product perception and behavioral intentions", Journal of Retailing and Consumer Services, Vol. 34 No. 2017, pp. 10-18, doi: 10.1016/j.jretconser.2016.09.005.

Leal, J.L.F.S. (2014), Pricing Strategies of the Supermarket Sector, [A project carried out on the management course, under the supervision of prof. Sofia Franco], available at: https://run.unl. pt/bitstream/10362/14908/1/Leal_2014.pdf.

Mamun, A., Rahman, M.K. and Robel, S.D. (2014), "A critical review of consumers' sensitivity to price: managerial and theoretical 1ssues", Journal of International Business and Economics, Vol. 2 No. 2, pp. 01-09, ISSN 2374-2208 (print) 2374-2194.

Mehrabian, A. and Russell, J.A. (1974), An Approach to Environmental Psychology, Massachhusetts Institue of Technology.

Mersin İl Kültür ve Turizm Müdürlügü (2021), "Mersin”, available at: https://mersin.ktb.gov.tr.

Meylina and Chandra, Y.U. (2018), "Analysis of higher education student's behavior factors to posting a comment on e-commerce with stimulus organism response (SOR) model", 2018 International Conference on Advanced Computer Science and Information Systems (ICACSIS), pp. 171-176, doi: 10.1109/ICACSIS.2018.8618183.

Mondal, S., Mall, M., Mishra, U.S. and Sahoo, K. (2017), "Investigating the factors affecting customer purchase activity in retail stores”, ESPACIOS, Vol. 38 No. 57, p. 22.

Mowen, J.C. and Minor, M. (2002), Perilaku Konsumen, Penerbit, Erlangga, Jakarta.

Noh, M., Lee, K., Kim, S. and Garrison, G. (2013), "Effects of collectivism on actual S-commerce use and the moderating effect of price consciousness", Journal of Electronic Commerce Research, Vol. 14 No. 3, pp. 244-260.

Noyan, F. and Şimşek, G.G. (2012), "A partial least squares path model of repurchase intention of supermarket customers”, Procedia- Social Behaviour, Vol. 62, pp. 921-926, doi: 10.1016/j.sbspro. 2012.09.156.

Pirachi, M. (2019), "Howard Sheth model”, available at: https:/theinvestorsbook.com/howard-shethmodel.html (accessed 14 November 2019).

Raminez, E. and Goldsmith, R.E. (2009), "Some antecedents of price sensitivity”, Journal of Marketing Theory and Practice, Vol. 17 No. 3, pp. 199-213, doi: 10.2753/MTP1069-6679170301.

Rana, S.M., Osman, A. and Othman, Y.H. (2015), "Factors affecting purchase intention of customers to shop at hypermarkets", Mediterranean Journal of Social Sciences, Vol. 6 No. 3, pp. 429-434, doi: 10.5901/mjss.2015.v6n3p429.

Sekaran, U. and Bougie, R. (2016), Research Method for Business. A Skill-Building Approach, John Wiley \& Sons, Chichester.

Consumers' price level

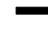


EJMBE 31,1

Shukla, M., Rasmussen, E.C. and Nestor, P.G. (2019), "Emotion and decision-making: induced mood influences IGT scores and selection strategies", Journal of Clinical and Experimental Psychology, Vol. 41 No. 4, pp. 341-352, doi: 10.1080/13803395.2018.1562049.

Spinelli, S. and Monteleone, E. (2018), "Emotional responses to products, 261-296", in Ares, G. and Varela, P. (Eds), Methods in Consumer Research, Woodhead Publishing, Duxford.

Turkish Statistical Institute [TurkStat] (2019), “Counties of Mersin”, available at: https://biruni.tuik. gov.tr/ilgosterge/?locale $=\operatorname{tr} /$ ?locale $=$ tr.

Uslu, A. and Huseynli, B. (2018), "Impact of price sensitivity on repurchase intention in terms of personality features", International Journal of Economic and Administrative Studies, Vol. 17 UiKK Special Issue, pp. 515-532, doi: 10.18092/ulikidince.434866.

Usman, A. and Okafor, S. (2019), "Exploring the relationship between social media and social influence", in Bowen, G. and Ozuem, W. (Eds), Leveraging Computer-Mediated Marketing Environments, IGI Global, pp. 83-103, doi: 10.4018/978-1-5225-7344-9.ch004.

Vergura, D.T., Zerbini, C. and Luceri, B. (2020), "Consumers' attitude and purchase intention towards organic personal care products. An application of the S-O-R model”, Sinergie Italian Journal of Management, Vol. 38 No. 1, pp. 121-137, doi: 10.7433/s111.2020.08.

Vieira, V.A. (2013), "Stimuli-organism-response framework: a meta-analytic review in the store environment", Journal of Business Research, Vol. 66 No. 9, pp. 1420-1426, doi: 10.1016/j.jbusres. 2012.05.009.

Wakefield, K.L. and Inman, J.J. (2003), "The situational price sensitivity: the role of consumption occasion, social context and income", Journal of Retailing, Vol. 79 No. 4, pp. 199-212, doi: 10. 1016/j.jretai.2003.09.004.

Walia, S.B., Kumar, H. and Negi, N. (2020), "Impact of brand consciousness, perceived quality of products, price sensitivity and product availability on purchase intention towards 'green' products", International Journal of Technology Management and Sustainable Development, Vol. 19 No. 1, pp. 107-118, doi: 10.1386/tmsd_00018_1.

Yao, J. and Oppewal, H. (2016), "Unit pricing increases price sensitivity even when products are of identical size", Journal of Retailing, Vol. 92 No. 1, pp. 109-121, doi: 10.1016/j.jretai.2015.09.002.

Zeithaml, V.A. (1988), "Consumer perceptions of price, quality and value: a means-end model and synthesis of evidence", Journal of Marketing, Vol. 52 No. 3, pp. 2-22, doi: 10.1177/ 002224298805200302.

Zhu, H., Yang, Z., Ou, C.X.J., Liu, H. and Davison, R.M. (2015), "Investing the impacts of recommendation agents on impulsive purchase behavior", Australasian Conference on Information Systems 2015, Adelaide.

Zielke, S. (2006), "Measurement of retailers' price images with a multiple-item scale", The International Review of Retail Distribution and Consumer Research, Vol. 16 No. 3, pp. 297-316, doi: 10.1080/ 09593960600696990.

Zielke, S. (2010), "How price image dimensions influence shopping intentions for different store formats", European Journal of Marketing, Vol. 44 No. 6, pp. 748-770, doi: 10.1108/ 03090561011032702.

Zielke, S. (2011), "Integrating emotions in the analysis of retail price images", Psychology and Marketing, Vol. 28 No. 4, pp. 297-316, doi: 10.1002/mar.20355.

\section{Corresponding author}

Sena Tekeli can be contacted at: sena.tekeli@toros.edu.tr

For instructions on how to order reprints of this article, please visit our website:

www.emeraldgrouppublishing.com/licensing/reprints.htm

Or contact us for further details: permissions@emeraldinsight.com 